\title{
PERKEMBANGAN PENAFSIRAN KONFESI-KONFESI YEREMIA
}

\author{
Chandra Julianto *
}

\begin{abstract}
Abstrak: Konfesi-konfesi Yeremia adalah salah satu bagian teks kenabian Perjanjian Lama yang sulit ditafsirkan makna dan tujuan penulisannya. Para ahli berusaha menggunakan berbagai metode penafsiran dalam mengeksegesis konfesi-konfesi Yeremia. Tulisan ini memaparkan dan meninjau perkembangan metode penafsiran yang digunakan para ahli tersebut, mulai dari penafsiran biografis, penafsiran historis-kritis, hingga penafsiran sinkronik yang ditandai dengan penggunaan analisis retorik. Berdasarkan natur dan karakteristik teks konfesi-konfesi Yeremia, penulis menyimpulkan bahwa analisis retorik adalah metode yang paling tepat dalam menafsirkan makna dan tujuan penulisan konfesi-konfesi Yeremia.
\end{abstract}

Abstract: Jeremiah's Confessions are considered as some of the most difficult Old Testament texts to be interpreted with respect to their meaning and purpose. Many Old Testament scholars throughout the years have used various methods to exegete Jeremiah's Confessions. This study aims to present and review these methods, hanging from biographical interpretation, historical criticism method, to the bloom of synchronic interpretation, defined by the use of rhetorical analysis. Based on the text's nature and characteristic, the study argues that rhetorical analysis is the most suited method to interpret the meaning and purpose of Jeremiah's Confessions.

Kata-kata Kunci: konfesi Yeremia, biografis, historis-kritis, sinkronik, analisis retorik, teks final, pesan retorik, dampak persuasif, respons pembaca.

* Penulis adalah alumni program M.Th. di Sekolah Tinggi Teologi Amanat Agung. Penulis dapat dihubungi melalui email: cj_cbs@hotmail.com. 


\section{Pendahuluan}

Kelima nas yang secara umum dikenal sebagai konfesi-konfesi Yeremia (11:18-12:6; 15:10-21; 17:14-18; 18:18-23; 20:7-18) merupakan teks kenabian Perjanjian Lama yang mendapatkan banyak perhatian. ${ }^{1} \mathrm{Di}$ tengah teks-teks kenabian Perjanjian Lama yang sarat dengan nubuat mengenai Yahweh, umat, dan bangsa-bangsa, konfesi-konfesi Yeremia yang memaparkan kondisi batin sang nabi dari sudut pandang orang pertama dianggap sebagai angin segar yang bukan hanya berbeda tetapi juga langka. ${ }^{2}$ Kelima nas ini pertama kali mendapat perhatian secara kritis dalam karya G. H. A. Ewald pada tahun 1840, yang secara sengaja memisahkan kelima nas ini dan melabelnya sebagai "konfesi",

1. Untuk keterangan lebih jauh mengenai ketertarikan para ahli kepada konfesi-konfesi Yeremia dan survei singkat mengenai perdebatan yang terjadi di dalamnya lihat Mark S. Smith, The Laments of Jeremiah and Their Contexts - A Literary and Redactional Study of Jeremiah 11-20 (Atlanta: Scholars Press, 1990), xiii-xiv; Thiele, The Identity of the "I" of the Confessions of Jeremiah, 12; Rebekah Jean Bedard, “The 'Pain-Filled Necessity' of Judgment: The Function of Jeremiah's Laments in Jeremiah 11-20" (University of St. Michael's College, 2010), 2-6; Diamond, "The Confessions of Jeremiah in Context-Scene of Prophetic Drama," 11-16; Carroll, From Chaos to Covenant: Uses of Prophecy in The Book of Jeremiah, 108.

2. Smith, The Laments of Jeremiah and Their Contexts, 1 menyatakan bahwa tidak seperti kitab kenabian yang lain, Kitab Yeremia "mengonsentrasikan dirinya secara dramatis" kepada kehidupan sang nabi sendiri. Pergeseran fokus yang cukup signifikan ini, menurut Smith, menjadi tanda tak terbantahkan bahwa dalam kitabnya, figur Yeremia menjadi salah satu pesan utama yang hendak disampaikan kepada pembaca, dan berdiri di tengah-tengah deskripsi figur sang nabi adalah konfesi-konfesinya. Bedard, "The 'Pain-Filled Necessity' of Judgment," 2 menyatakan bahwa kitab Yeremia adalah salah satu kitab kenabian terpanjang yang memuat nubuat-nubuat mengenai bangsa Israel, Yehuda, dan bangsa-bangsa asing, tetapi tetap saja yang menjadi fokus utama dari kitab ini adalah kehidupan sang nabi sendiri. 
mengimplikasikan perbedaan genre antara kelima nas ini dengan nasnas lain dalam Kitab Yeremia. ${ }^{3}$ Sejak saat itu, berbagai tafsiran mulai muncul untuk membahas makna dan tujuan penulisan konfesi Yeremia. Tulisan ini bertujuan melihat perkembangan penafsiran konfesi-konfesi Yeremia, mulai dari penafsiran biografis, penafsiran historis-kritis, hingga penafsiran sinkronik yang ditandai dengan metode analisis retorik, dan menilai metode penafsiran manakah yang paling tepat dalam eksegesis konfesi-konfesi Yeremia.

\section{Penafsiran Biografis}

Tafsiran-tafsiran awal melihat kelima konfesi-konfesi Yeremia sebagai karya biografis. ${ }^{4}$ Para ahli yang menganut pandangan ini percaya bahwa kelima konfesi Yeremia ditulis sendiri oleh sang nabi dan muridnya, Barukh, dengan tujuan untuk mengungkapkan kondisi psikologis Yeremia di tengah tekanan pelayanan kenabiannya. ${ }^{5}$

3. Jack R. Lundbom, Jeremiah Among The Prophets (Eugene: Cascade Books, 2012), 48 mengungkapkan bahwa secara genre, sebenarnya teks konfesi-konfesi Yeremia termasuk ke dalam genre mazmur ratapan individual. Namun, kelima teks ini dikenal secara luas sebagai "konfesi" karena kemiripannya dengan konfesi dari Santo Agustinus. Lihat juga A. R. Diamond, "The Confessions of Jeremiah in Context-Scene of Prophetic Drama," JSOT Supplement Series 45, 1987, 11; David Thiele, The Identity of the "I" of the Confessions of Jeremiah (Lambert, 2014), 13; Robert P. Carroll, From Chaos to Covenant: Uses of Prophecy in The Book of Jeremiah (London: SCM, 1981), 59.

4. Willem A. VanGemeren, Interpreting The Prophetic Word: an Introduction to the Prophetic Literature of the Old Testament (Grand Rapids: Zondervan, 2002), 296-97.

5. C. F. Keil, "Jeremiah, Lamentations," dalam Commentary on the Old Testament in Ten Volumes, ed. C. F. Keil dan F. Delitzsch, vol. VIII (Grand Rapids: Eerdmans, t.t.), 11, 18; Nolan B. Harmon, ed., "Jeremiah," dalam The 
Perhatian biografis terhadap konfesi Yeremia pertama kali diungkapkan oleh John Skinner dalam karyanya Prophecy and Religion: Studies in the Life of Jeremiah pada tahun 1922. Skinner melihat konfesi-konfesi Yeremia memiliki tujuan yang berbeda dengan nubuat-nubuatnya. Sementara nubuat-nubuat Yeremia lahir dari panggilannya sebagai seorang nabi, konfesi-konfesinya lahir dari keberadaan dirinya sebagai seorang manusia. Jika nubuat-nubuat Yeremia ditujukan untuk mengarahkan publik, konfesinya ditujukan sebagai ungkapan hati personal. ${ }^{6}$ Pendapat Skinner ini mendapatkan legitimasi dalam paparan Walter Baumgartner yang mengategorikan konfesi-konfesi Yeremia

Interpreter's Bible, vol. VI (New York: Abingdon, 1956), 782; Sheldon H. Blank, Jeremiah: Man and The Prophet (Cincinnati: Hebrew Union College, 1961), 3; Roger Vanden Busch, "Jeremiah: A Spiritual Metamorphosis," Biblical Theology Bulletin 10/1 (1980): 23; Kathleen M. O'Connor, "The Prophet of Jeremiah and Exclusive Loyalty to God," Vocation 59/2 (2005): 131; T. K. Cheyne, Jeremiah, Lamentations, The Pulpit Commentary vol. 11, ed. H. D. M. Spence dan Joseph S. Exell (Peabody: Hendrickson, 1985), xi-xii; Tremper Longman III, Jeremiah, Lamentations, New International Biblical Commentary (Peabody: Hendrickson, 2008), 3, 68; Lawrence Boadt, "The Book of Jeremiah and The Power of Historical Recitation," dalam Troubling Jeremiah, JSOT Supplement Series 260, (England: Sheffiled Academics Press, 1999), 339; J. A. Thompson, The Book of Jeremiah (Grand Rapids: Eerdmans, 1980), 41; Gerhard von Rad, The Message of the Prophets, terj. D. M. G. Stalker (New York: Harper Collins, 1965), 18; William Neil, Bible Guides 8: Prophets of Israel vol. 2: Jeremiah and Ezekiel, ed. William Barclay dan F. F. Bruce, (New York: Abingdon, 1964), 22; Philip J. King, Jeremiah: An Archeological Companion (Louisville: Westminster, 1993), 9.

6. Lihat pembahasan Skinner mengenai konfesi-konfesi Yeremia dalam John Skinner, Prophecy and Religion: Studies in The Life Of Jeremiah (Cambridge: The Syndics of The Cambridge University Press, 1963), 201-30; Pengakuan terhadap dampak dari karya Skinner dalam pembentukan penafsiran biografis terhadap konfesi-konfesi Yeremia diberikan oleh beberapa ahli seperti Thiele, The Identity of the " $I$ " of the Confessions of Jeremiah, 13; Walter Brueggemann, "Next Steps in Jeremiah Studies?," 11; Bedard, "The 'Pain-Filled Necessity' of Judgment," 2. 
bukan ke dalam genre nubuat, tapi ke dalam genre mazmur ratapan individual. ${ }^{7}$ Sheldon H. Blank dan Philip J. King membawa pendapat Baumgartner lebih jauh dan menyebut konfesi Yeremia sebagai doa pribadi. ${ }^{8}$ Semua pendapat ini sama-sama melihat konfesi Yeremia sebagai ungkapan personal yang hanya melibatkan dua pihak: Yahweh dan sang nabi sendiri.

Dalam perkembangan berikutnya, penafsiran biografis mulai melihat konfesi Yeremia dalam ruang lingkup yang lebih sempit. Konfesi Yeremia tidak lagi dilihat sebagai ungkapan hubungan personal antara sang nabi dengan Yahweh, melainkan sebagai percakapan antara sang nabi dengan dirinya sendiri. Michael Avioz menyebut konfesi Yeremia sebagai 'monolog batiniah'. ${ }^{9}$ Nicholson dan Devolder melihat konfesi

7. Walter Baumgartner, Historic Texts and Interpreters Biblical Scholarship 7: Jeremiah's Poems of Lament, terj. David E. Orton, (Sheffield: Almond Press, 1987), 95-96. Untuk keterangan lebih jauh mengenai signifikansi penelitian Baumgartner mengenai genre konfesi Yeremia sebagai mazmur ratapan lihat Bedard, "The 'Pain-Filled Necessity' of Judgment," 2; Thiele, The Identity of the "I" of the Confessions of Jeremiah, 14; Diamond, "The Confessions of Jeremiah in Context," 12; William L. Holladay, "Indications of Jeremiah's Psalter," Journal of Biblical Literature 121/2 (2002): 245; Longman III, Jeremiah, Lamentations, 14; John Bright, "A Prophet's Lament and It's Answer: Jeremiah 15:10-21," ed. James L. Mays, Interpretation 28/1 (1974): 59, 64; Patrick D. Miller, Jr., "Trouble and Woe: Interpreting The Biblical Laments," Interpretation 37 (1983): 40; Timothy Polk, The Prophetic Persona: Jeremiah and The Language of Self, ed. David J. A. Clines dan Philip R. Dabies, JSOT Supplement Series 32, 1984, 127; von Rad, The Message of the Prophets, 171; Gerhard von Rad, Old Testament Theology, vol. 2 (New York: Harper \& Row, 1965), 201.

8. Sheldon H. Blank, "The Confessions of Jeremiah and The Meaning of Prayer," Hebrew Union College Annual 21 (1948): 331; Blank, Jeremiah, 105; King, Jeremiah: An Archeological Companion, 6.

9. Michael Avioz, "The Call For Revenge in Jeremiah's Complaints (Jer XI-XX)," Vetus Testamentum 55/4 (2005): 431. 
Yeremia sebagai media katarsis bagi sang nabi yang ada di bawah tekanan psikologis yang besar. $^{10}$ Sementara itu, William Neil menyatakan bahwa deskripsi pergumulan Yeremia dalam konfesikonfesinya hanyalah sebuah bahasa metafora yang digunakan oleh sang nabi untuk mendamaikan pergolakan batin yang dialaminya. ${ }^{11}$ Lambat laun, penafsiran biografis melihat konfesi-konfesi Yeremia tak ubahnya seperti buku harian yang mengungkapkan profil psikologis sang nabi, sebagaimana pengamatan Gerhard von Rad, “... ada perpindahan dalam perhatian utama kenabian Yeremia, dari pesan kenabian kepada pribadi yang menyampaikan pesan itu." 12

Selama beberapa waktu, penafsiran biografis mendominasi pembahasan makna dan tujuan penulisan konfesi Yeremia dan sudah dianggap sebagai pandangan klasik. Namun pada perkembangan berikutnya, penafsiran ini mulai ditinggalkan karena beberapa alasan. Pertama, penafsiran biografis dilihat terlalu dipaksakan karena kita tidak benar-benar memiliki catatan biografis yang lengkap tentang Yeremia. Data yang kita miliki hanyalah beberapa narasi dan puisi yang

10. Ernest W. Nicholson, The Book of The Prophet Jeremiah: Chapters 125 (London: Cambridge University Press, 1973), 114; Rachelle Devolder, "The Sufferings of The Prophet of Jeremiah and Their Results" (Tesis M.A., University of Ottawa, 1971), 102.

11. Neil, Prophets of Israel vol. 2: Jeremiah and Ezekiel, 21, 31.

12. Dikutip dari Polk, The Prophetic Persona: Jeremiah and The Language of Self, 7 yang juga mengutip Gerhard Von Rad, Old Testament Theology, terj. D. M. G. Stalker, II (New York: Harper and Row, 1965), 197, 201. Lihat juga John Goldingay, God's Prophet God's Servant: A Study in Jeremiah and Isaiah 40-55 (Greenwood: Attic, 1984), 15 
menceritakan beberapa momen kritis dalam kehidupan sang nabi. ${ }^{13}$ Sulit rasanya untuk menggambarkan profil Yeremia dengan data yang tidak lengkap, apalagi kondisi psikologisnya.

Kedua, nampaknya penulis konfesi Yeremia sendiri tidak memaksudkan konfesi-konfesi ini sebagai sumber biografis sang nabi. Menurut Brueggemann, ide akan sebuah profil biografis hanya ada dalam pemikiran dunia modern. Sementara dalam dunia Perjanjian Lama, penggambaran personal dari seorang tokoh digunakan untuk menekankan maksud teologis. ${ }^{14}$ Hal yang sama juga disampaikan oleh Childs. Menurutnya, konfesi Yeremia bukanlah ungkapan hati sang nabi yang terpisah dari panggilan kenabiannya, melainkan justru diungkapkan sebagai strategi untuk memperkuat pesan nubuat yang disampaikan. ${ }^{15}$ Gambaran seorang nabi Yahweh yang putus asa dalam pelayanannya bicara lebih banyak dan lebih tajam tentang kejahatan Yehuda daripada sekadar mendeskripsikan kejahatan itu dalam bentuk nubuat. ${ }^{16}$

Ketiga, seluruh penafsiran biografis didasarkan kepada asumsi bahwa Yeremia dan Barukh yang menulis konfesi ini. Namun, beberapa kejanggalan di dalam teks Yeremia, seperti keterpisahan antara nubuat

13. Jack R. Lundbom, "Jeremiah, Book of," dalam The Anchor Bible Dictionary vol. 3: H-J, ed. David Noel Freedman (New York: Doubleday, 1992), 710.

14. Walter Brueggemann, The Theology of The Book of Jeremiah (Cambridge: Cambridge University Press, 2007), LXX.

15. Brevard S. Childs, Old Testament Theology in a Canonical Context (Philadelphia: Fortress, 1985), 124.

16. Brevard S. Childs, Introduction to the Old Testament as Scripture (Philadelphia: Fortress, 1979), 349-50. 
dengan narasi kejadian yang melatarbelakanginya (misalnya: pasal 7 dan 26, pasal 25 dan 36), pengelompokan nonkronologis kelima konfesi Yeremia ke dalam pasal 11-20, dan kejanggalan-kejanggalan lain, membuat para ahli percaya bahwa kitab Yeremia telah melalui proses editorial, bukan lagi murni karya Yeremia dan Barukh. ${ }^{17} \mathrm{Hal}$ ini mengakibatkan penafsiran biografis mulai ditinggalkan, dan era baru, yang ditandai oleh penafsiran historis-kritis, dimulai.

\section{Penafsiran Historis Kritis}

Penafsiran historis-kritis berusaha mengembalikan teks konfesi Yeremia kepada bentuk dan susunan awalnya sebelum proses redaksi terjadi. Penafsiran ini berasumsi bahwa makna dan tujuan penulisan konfesi Yeremia baru bisa disimpulkan ketika teks ada dalam bentuk dan susunan strukturnya yang paling awal. Di antara semua usaha penafsiran historis-kritis terhadap konfesi Yeremia, mungkin yang paling dikenal secara luas adalah penelitian Sigmund Mowinckel dan Bernhard Duhm.

17. Untuk pembahasan lebih jauh lihat von Rad, The Message of the Prophets, 15; Herrmann Siegfried, "Overcoming the Israelite Crisis. Remarks on the Interpretation of the Book of Jeremiah," dalam A Prophet to the Nations: Essays in Jeremiah Studies, ed. Leo G. Perdue dan Brian W. Kovacs, terj. Leo G. Perdue (Winona Lake: Eisenbrauns, 1984), 301; Harmon, The Interpreter's Bible, V: 787; Lundbom, "Jeremiah, Book of," 1992, 711; Childs, Introduction to the Old Testament as Scripture, 342. Penelitian terbaru mengenai bukti-bukti bahwa proses editorial terjadi atas kitab Yeremia dilakukan oleh Devorah Dimant, "From The Book of Jeremiah to the Qumranic Apocryphon of Jeremiah," Dead Sea Discoveries 20 (2013): 452-71. Dimant membuktikan melalui Gulungan Laut Mati bahwa pada masa pasca pembuangan Kitab Yeremia masih belum mendapatkan bentuk yang pasti, yang membuktikan bahwa ada proses editorial yang berlangsung melewati masa hidup sang nabi dan bahkan Barukh. 
Mowinckel dan Duhm menyatakan bahwa ada 3 sumber dalam kitab Yeremia: sumber $\mathrm{A}$ berisi nubuat asli Yeremia, termasuk konfesikonfesinya; sumber B berisi kisah-kisah kehidupan personal sang nabi yang ditulis oleh Barukh dan murid-murid Yeremia yang lain; sumber $\mathrm{C}$ berisi prosa-prosa, termasuk bagian pendahuluan dan kesimpulan, yang ditambahkan oleh editor deuteronomistik. ${ }^{18}$

Berdasarkan keterangan dalam pasal 36, kita mengetahui setidaknya ada 3 tahapan yang dilalui oleh teks konfesi-konfesi Yeremia. Menurut Yeremia 36:2, Yeremia diperintahkan Yahweh untuk menulis sebuah gulungan kitab yang berisi "segala perkataan yang telah Kufirmankan kepadamu mengenai Israel, Yehuda dan segala bangsa, dari sejak Aku berbicara kepadamu, yakni dari sejak zaman Yosia, sampai waktu ini." (ay. 2 TB-LAI). Kitab ini ditulis oleh Barukh dengan cara didiktekan oleh Yeremia secara langsung dan dibacakan tiga kali: di depan Bait Allah, di depan pejabat istana, dan di depan raja Yoyakim (ay.

18. Untuk keterangan lebih jauh mengenai paparan Duhm dan Mowinckel tentang berbagai sumber Kitab Yeremia lihat pembahasan Thompson, The Book of Jeremiah, 35-40; Peter C. Craigie, Page H. Kelley, dan Joel F. Drinkard Jr., Jeremiah 1-25, Word Biblical Commentary 26 (Nashville: Thomas Nelson, 1991), xxxii; Brueggemann, The Theology of The Book of Jeremiah, 2-3; John Bright, Jeremiah: Introduction, Translation, and Notes, The Anchor Bible (New York: Doubleday, 1965), LX, LXIII; Childs, Introduction to the Old Testament as Scripture, 342; dan Jack R. Lundbom, Jeremiah 1-20: A New Translation with Introduction and Commentary, The Anchor Yale Bible (London: Yale University Press, 2009), 64. Yang secara langsung berinteraksi dengan karya Duhm; Bernhard Duhm, Das Buch Jeremia (Charleston: Nabu Press, 2011); dan karya Mowinckel Sigmund Mowinckel, Zur Komposition Des Buches Jeremia (USA: Wentworth, 2016). 
$10,15,21)$. Inilah sumber A yang mencakup nubuat-nubuat asli Yeremia termasuk konfesi-konfesinya.

Berdasarkan keterangan dalam Yeremia 36:23, kita mengetahui bahwa raja Yoyakim menolak semua nubuat yang ditulis di dalam gulungan kitab pertama dan bahkan membakarnya. Menanggapi tindakan ini, Yahweh memerintahkan Yeremia untuk menulis gulungan Kitab kedua yang berisi semua nubuat yang dituliskan di gulungan pertama dengan tambahan nubuat tentang raja Yoyakim dan pembuangan ke Babel (ay. 28-32). Bercermin dari peristiwa sebelumnya, tidak mungkin gulungan kedua ini diserahkan lagi kepada elit politik dan pemimpin religius Yerusalem, sehingga kemungkinan yang paling bisa diterima adalah gulungan kitab kedua ini diserahkan kepada mereka yang mempercayai Yeremia sebagai nabi sejati. ${ }^{19}$ Inilah sumber $B$ yang berisi nubuat asli Yeremia, konfesi-konfesinya, dan penambahan kisah personal dari murid-murid sang nabi.

Kita tidak tahu kapan akhirnya teks Yeremia mendapatkan bentuk finalnya, tetapi keterangan dalam teks pasal 11-20 yang sarat dengan nubuat mengenai pembuangan ke Babel dan kejadian-kejadian tragis yang menyertainya (lih. Yer. 11:22-23; 13:20; 15:13-14; 16:13-15; 18:2122; 20:4-6), menunjukkan bahwa teks final konfesi-konfesi Yeremia

19. Kathleen M. O'Connor, "The Confessions of Jeremiah: Their Interpretation and Role in Chapters 1-25," Society of Biblical Literature, Dissertation Series, 94 (1988): 95; Bedard, "The 'Pain-Filled Necessity' of Judgment," 63. 
diteruskan kepada umat pembuangan. ${ }^{20}$ Inilah sumber $\mathrm{C}$ yang dipercaya merupakan hasil redaksi editor deuteronomistik. ${ }^{21}$

Penafsiran historis-kritis sebenarnya membawa eksegesis terhadap konfesi Yeremia ke arah yang benar. Kejanggalan-kejanggalan yang ditemukan di dalam teks konfesi Yeremia memang hanya bisa dijelaskan jika ada proses editorial terlibat di dalamnya. Namun survei hasil penafsiran historis-kritis terhadap konfesi Yeremia menunjukkan bahwa usaha pengembalian teks kepada bentuk dan susunan asalnya adalah hal yang mustahil dilakukan. Bentuk final konfesi-konfesi Yeremia begitu kompleks dan terjalin satu sama lain sehingga kita tidak bisa lagi

20. Walter Brueggemann, A Commentary on Jeremiah-Exile and Homecoming (Grand Rapids: Eerdmans, 1998), 1; Brueggemann, The Theology of The Book of Jeremiah, 51; John Bright, Jeremiah, Anchor Bible 21 (Garden City: Doubleday, 1981), Ixvi; Bedard, "The 'Pain-Filled Necessity' of Judgment," 63; Terence E. Fretheim, Jeremiah, Smyth \& Helwys Bible Commentary (Georgia: Smyth \& Helwys, 2002), 182; dan Dorothy E. Siebert, "Jeremiah: A Model for Response to Persecution and Threats of Violence" (Tesis M..A. Providence Theological Seminary, 2007), 21.

21. Hampir semua ahli kitab Yeremia seperti Geoffrey H. Parke-Taylor, The Formation of The Book of Jeremiah: Doublets and Recurring Phrases, Monograph Series 51 (Atlanta: Society of Biblical Literature, 2000), 292; Bedard, "The 'Pain-Filled Necessity' of Judgment," 1; O'Connor, "The Confessions of Jeremiah," 2; Siebert, "Jeremiah," 9; H. H. Rowley, "The Prophet and Jeremiah and The Book of Deuteronomy," dalam Studies in Old Testament Prophecy, ed. H. H. Rowley (New York: T \& T Clark, 1957), 157-74; King, Jeremiah: An Archeological Companion, 9; Siegfried, "Overcoming the Israelite Crisis," 300; Brueggemann, The Theology of The Book of Jeremiah, 27; Childs, Introduction to the Old Testament as Scripture, 347; Brueggemann, The Theology of The Book of Jeremiah, 2; Brevard S. Childs, Biblical Theology of the Old and New Testaments: Theological Reflection on The Christian Bible (Minneapolis: Fortress, t.t.), 178; Craigie, Kelley, dan Drinkard Jr., Jeremiah 1-25, xxxiii sepakat bahwa proses editorial yang terjadi atas kitab Yeremia adalah karya para editor deuteronomistik. 
menentukan dengan pasti bagian mana yang berasal dari tulisan Yeremia, bagian mana dari Barukh, atau hasil redaksi editor deuteronomistik. Hal ini menyebabkan semua usaha penafsiran historiskritis terhadap konfesi-konfesi Yeremia penuh dengan spekulasi subjektif dan hanya mampu menghasilkan fragmentasi tafsiran yang terlalu beragam tanpa adanya konsensus pendapat mengenai bentuk dan susunan asli konfesi-konfesi Yeremia. ${ }^{22}$ Absennya kesepakatan ini pada akhirnya menyebabkan penafsiran historis-kritis tidak pernah dapat beranjak kepada pembahasan mengenai makna dan tujuan penulisan konfesi-konfesi Yeremia, sebagaimana kritik Tremper Longman III, "Usaha-usaha untuk menelusuri setiap perubahan yang ada di dalam kitab Yeremia justru berbahaya dan malah mengalihkan kita dari pesan utama kitab."23 Lambat laun penafsiran historis-kritis mulai ditinggalkan, sebagaimana kesimpulan Leo G. Perdue, "pendekatan historis yang bersifat merekonstruksi sejarah pembentukan kitab Yeremia sudah runtuh." ${ }^{24}$

\section{Penafsiran Sinkronik}

Gagalnya penafsiran historis-kritis menemukan makna dan tujuan penulisan konfesi, akhirnya mendorong studi konfesi-konfesi Yeremia

22. Craigie, Kelley, dan Drinkard Jr., Jeremiah 1-25, xxxiii; Jack R. Lundbom, Jeremiah Closer Up: The Prophet and The Book (Sheffield: University of Sheffield, 2010), ix; Childs, Biblical Theology of the Old and New Testaments, 203, 204; Childs, Old Testament Theology in a Canonical Context, 4; Don H. Compier, What is Rhetorical Theology? (Harrisburg: Trinity, 1999), vii.

23. Longman III, Jeremiah, Lamentations, 5.

24. Perdue, "The Book of Jeremiah in old Testament Theology," 323. 
melangkah ke arah yang baru, yaitu ke arah penafsiran sinkronik. ${ }^{25}$ Penafsiran sinkronik tidak melihat sebuah teks sebagai keberadaan yang berdiri sendiri, melainkan sebagai bagian dari unit teks yang lebih besar di mana semua teks saling berkontribusi untuk membentuk makna dalam unit teks yang lebih besar. ${ }^{26}$ Penafsiran sinkronik sebenarnya terpengaruh banyak dari metode penafsiran kanonik Brevard S. Childs. ${ }^{27}$ Childs setuju dengan pendapat para ahli historis-kritis bahwa teks Alkitab, di dalam bentuk finalnya, adalah hasil proses redaksi yang berusaha membawa makna teks ke dalam terang kebutuhan kontemporer. ${ }^{28}$ Namun daripada berusaha menelusuri perubahan-

25. Walter Brueggemann, Like Fire in the Bones: Listening for the Prophetic Word in Jeremiah, ed. Patrick D. Miller (Minneapolis: Fortress, 2006), 56; Childs, Biblical Theology of the Old and New Testaments, 204.

26. Kita bisa melihat contoh penafsiran sinkronik terhadap teks konfesikonfesi Yeremia dari tafsiran beberapa ahli seperti Diamond, Smith, Thiele, dan O'Connor. Diamond, Smith dan Thiele sama-sama meletakkan konfesi Yeremia dalam kerangka pembahasan pasal 11-20. O'Connor melakukan hal yang berbeda. Sekalipun dia melihat konfesi Yeremia memang dikelompokkan ke dalam konteks pasal 11-20, tetapi konteks pasal 11-20 ini pun merupakan bagian dari konteks yang lebih besar, yaitu pasal 1-25. Oleh sebab itu O' Connor membawa pembahasannya mengenai konfesi Yeremia ke dalam kerangka pembahasan pasal 1-25. Untuk keterangan lebih jauh lihat Diamond, "The Confessions of Jeremiah in Context," 177, 189; Smith, The Laments of Jeremiah and Their Contexts, 1; Thiele, The Identity of the "l" of the Confessions of Jeremiah, 64, 129; O'Connor, "The Confessions of Jeremiah," 115, 137, 158; Kathleen M. O'Connor, Jeremiah: Pain and Promise (Minneapolis: Fortress, 2011), 31,34; Kathleen M. O'Connor, "The Tears of God and Divine Encounter," dalam Troubling Jeremiah, JSOT Supplement Series 260, 1999, 401.

27. Robin Routledge, Old Testament Theology: A Thematic Approach (Nottingham, England: Apollos, 2008), 56; Daniel R. Driver, "Childs as Biblical Theologian," dalam The Bible as Christian Scripture: The Work of Brevard S. Childs, SBL Supplement Series 25 (Atlanta: SBL, 2013), 253.

28. Childs, Biblical Theology of the Old and New Testaments, 70; Brevard S. Childs, The Struggle to Understand Isaiah as Christian Scripture (Grand Rapids: 
perubahan yang sudah dialami teks, Childs lebih tertarik untuk mengetahui intensi dan tujuan teologis di balik proses redaksi yang terjadi. ${ }^{29}$ Menurut Childs, jika proses redaksi sengaja dilakukan untuk membawa teks kepada bentuk finalnya, kita dapat mengasumsikan bahwa bentuk final inilah yang diharapkan untuk dipahami oleh para pembacanya. ${ }^{30}$ Dengan demikian, usaha menelusuri teks ke belakang sampai kepada bentuk dan susunan awalnya sebenarnya bertentangan dengan maksud progresif yang diharapkan oleh teks itu sendiri. ${ }^{31}$ Menurut Childs metode yang paling tepat untuk menafsirkan teks final Alkitab ada di dalam payung besar metode bahasa literer. ${ }^{32}$ Brueggemann menyatakan bahwa dalam kasus penafsiran teks Yeremia secara spesifik, metode bahasa literer yang tepat adalah analisis retorik. $^{33}$

Eerdmans, 2004), 321; Childs, Introduction to the Old Testament as Scripture, 67.

29. Childs, Old Testament Theology in a Canonical Context, 125; Childs, Introduction to the Old Testament as Scripture, 35, 67, 76; Routledge, Old Testament Theology, 56; Christopher R. Seitz, "Tribute to Brevard S. Childs at The International SBL Meeting in Vienna, Austria," dalam The Bible as Christian Scripture-The Work of Brevard S. Childs, SBL Supplement Series 25 (Atlanta: SBL, 2013), 4

30. Childs, Biblical Theology of the Old and New Testaments, 109; Childs, Old Testament Theology in a Canonical Context, 9; C. Kavin Rowe, "The Doctrine of God Is a Hermeneutic: The Biblical Theology of Brevard S. Childs," dalam The Bible as Christian Scripture-The Work of Brevard S. Childs, SBL Supplement Series 25 (Atlanta: SBL, 2013), 157.

31. Roy A. Harrisville dan Walter Sundberg, The Bible in Modern Culture: Baruch Spinoza to Brevard Childs, ed. kedua (Grand Rapids: Eerdmans, 2002), 315.

32. Childs, Biblical Theology of the Old and New Testaments, 204.

33. Brueggemann, Like Fire in the Bones: Listening for the Prophetic Word in Jeremiah, 60; Brueggemann, "Next Steps in Jeremiah Studies?," 409. 


\section{Analisis Retorik}

Analisis retorik sebenarnya bukanlah metode baru dalam dunia hermeneutika Alkitab. Analisis retorik sudah mendapat pengakuan dalam karya bapa gereja Agustinus De Doctrina pada tahun 426/427 M. ${ }^{34}$ Hanya saja kala itu, menurut Agustinus, analisis retorik hanya berfungsi dalam dunia homiletika, yaitu sebagai cara persuasif mengajarkan kebenaran Alkitab dengan efektif. Pendapat ini terus dipertahankan dalam zaman-zaman berikutnya sehingga kita tidak banyak melihat penggunaan analisis ini dalam tulisan para bapa-bapa gereja atau tokoh-tokoh reformasi. ${ }^{35}$ Secara umum diakui bahwa

34. Menurut Anderson, Ancient Rhetorical Theory and Paul, 17 sebelum Agustinus menjadi seorang Kristen, dia adalah seorang profesor dalam bidang retorika, dan pengalaman ini -sedikit banyak-membentuk pemahaman Agustinus tentang penafsiran Alkitab. Menurut Agustinus, para penulis Alkitab adalah para orator hebat yang menggabungkan inspirasi ilahi dengan kemampuan persuasif dalam tulisan-tulisan mereka, sehingga para pembaca dapat diyakinkan kepada kebenaran yang disampaikan dan mengikutinya. Alkitab tidak pernah dimaksudkan sekadar untuk memperkaya pengetahuan saja, melainkan juga untuk mendorong tindakan nyata. Agar tujuan Alkitab ini sepenuhnya tercapai, seorang penafsir Alkitab tidak boleh hanya mengetahui cara menarik keluar makna Alkitab, melainkan juga harus memahami cara penyampaian yang dapat memastikan pendengarnya bertindak. Oleh sebab itu, menurut Agustinus, para pengajar Alkitab bukan hanya harus memiliki kemampuan hermeneutika, melainkan juga kemampuan retorika agar kekuatan persuasif yang dimiliki Alkitab bisa sepenuhnya terealisasi. Lihat juga James Andrews, "Why Theological Hermeneutics Needs Rhetoric: Augustine's De doctrina Christiana," IJST 12/2 (2010): 185, 188.

35. Menurut Anderson, Jr., Ancient Rhetorical Theory and Paul, 19-20 selepas Agustinus, tokoh berikutnya secara ekstensif menggunakan retorika klasik di dalam penafsiran Kitab Sucinya adalah Philip Melanchthon. Melanchton bukan hanya mempelajari retorika klasik, tetapi dia juga mengajarkan penggunaan retorika klasik dalam penafsiran Alkitab dan menulis beberapa buku tentang hal ini: De Rhetorica Libri Tres di tahun 1519, Institutiones Rhetoricae di tahun 1521, dan Encomium Eloquentiae di tahun 1523. Berbeda 
momen penerimaan analisis retorik sebagai metode hermeneutika Alkitab yang sah terjadi pada tahun 1968 ketika James Muilenburg membahas analisa ini di dalam pidato tahunannya sebagai presiden Society of Biblical Literature. $^{36}$ Dalam pidatonya ini, Muilenburg menyatakan bahwa analisis retorik harus mulai mendapat perhatian khusus di dalam dunia hermeneutika Alkitab sebab analisis retorik dapat menjadi jalan tengah yang mampu melihat teks Alkitab sebagai sebuah literatur yang dapat diselidiki secara kritis dan di saat yang sama mengakui nilai spiritualnya sebagai sebuah karya rohani yang dapat

dengan Agustinus yang menganggap retorika klasik hanya dapat berfungsi pada bidang praktika seperti penyampaian khotbah atau pengajaran Alkitab, Melanchton melihat retorika klasik dapat memberikan kontribusi pada bidang hermeneutika Alkitab. Menurut Melanchton, retorika klasik bisa dipakai untuk menentukan bagian teks mana yang menjadi ide utama penulis, dilihat dari perbedaan penekanan persuasif yang diberikan. Semakin sebuah bagian teks mendapatkan penekanan persuasif, tentulah bagian itu dianggap lebih penting oleh penulis, dan dengan demikian, merupakan bagian utama dari teks tersebut. Metode ini diaplikasikan oleh Melanchton dalam tafsirannya tentang surat Galatia, Roma, dan Kolose. Sayangnya, selepas Melanchton, kita tidak menemui lagi penggunaan dari analisis retorik dalam penafsiran Alkitab sampai kepada kebangkitannya kembali 300 tahun kemudian dalam universitasuniversitas sekuler di Amerika Serikat. Untuk keterangan lebih jauh lihat juga; Jack R. Lundbom, Jeremiah: A Study in Ancient Hebrew Rhetoric (Winona Lake: Eisenbrauns, 1997), xix-xxiv; Lundbom, Jeremiah 1-20, 68-70.

36. Menurut Lundbom, Anderson, dan Scult, sebenarnya analisis retorik sudah digunakan untuk menafsirkan Alkitab sejak tahun 1920-an atau 45 tahun sebelum Muilenburg membawakan pidato kepresidenannya yang terkenal. Namun para tokoh ini tidak memberikan definisi dan langkah-langkah metodologikal sejelas Muilenburg, sehinga Muilenburglah yang diakui secara luas sebagai pelopor penggunaan analisis retorik dalam penafsiran Alkitab. Untuk keterangan lebih jauh lihat Lundbom, Jeremiah: A Study in Ancient Hebrew Rhetoric, xxvii; Lundbom, Jeremiah 1-20, 70; dan Anderson, Jr., Ancient Rhetorical Theory and Paul, 23; Dale Patrick dan Allen Scult, Rhetoric and Biblical Interpretation (Sheffield: The Almond Press, 1990), 12. 
mempengaruhi pembacanya secara personal. ${ }^{37}$ Sejak saat itu, analisis retorik dikenal secara luas sebagai metode hermeneutika yang sah dan usaha-usaha integrasi analisis retorik dengan metode-metode hermeneutika yang lain mulai muncul. ${ }^{38}$

Ada beberapa karakteristik dalam analisis retorik. Pertama, analisis retorik berfokus kepada teks final kitab. Analisis retorik melihat semua perubahan yang dialami teks sebelum bentuk finalnya tidak penting sebab teks yang diterima pembaca adalah teks final. Semua proses redaksi yang terjadi di dalam teks disengaja untuk membentuk pesan retorik yang partikular dalam rangka menimbulkan dampak persuasif yang partikular pula. Tugas penafsir bukanlah menggugat proses redaksi yang terjadi, melainkan menganalisa pesan retorik dan dampak persuasif yang partikular tersebut. ${ }^{39}$

37. David Greenwood, "Rhetorical Criticism and Formgeschichte: Some Methodological Considerations," JBL 89 (1970): 418; Leslie C. Allen, "The Value of Rhetorical Criticism in Psalm 69," JBL 105/4 (1986): 577; Wilhelm Wuellner, "Reconceiving a Rhetoric of Religion: A Rhetoric of Power as the Power of The Sublime," dalam Rhetorics and Hermeneutics, ed. James D. Hester dan J. David Hester (London: T \& T Clark, 2004), 23.

38. Michal Beth Dinkler, "New Testament Rhetorical Narratology: An Invitation toward Integration," JBL 24 (2016): 203-28 membahas tentang integrasi analisis retorik dengan analisa naratif; Greenwood, "Rhetorical Criticism and Formgeschichte: Some Methodological Considerations" membahas tentang integrasi analisis retorik dengan metode analisa bentuk; membahas tentang aplikasi analisis retorik di dalam interpretasi genre puisi di dalam Perjanjian Lama Allen, "The Value of Rhetorical Criticism in Psalm 69"; bahkan membahas tentang penggunaan analisis retorik di dalam bidang teologi sistematika Compier, What is Rhetorical Theology?

39. Jack R. Lundbom, Biblical Rhetoric and Rhetorical Criticism, Hebrew Bible Monographs 45 (Sheffield: Sheffield Phoenix Press, 2015), 28; Lundbom, Jeremiah: A Study in Ancient Hebrew Rhetoric, xxii; Boadt, "The Book of Jeremiah 
Kedua, analisis retorik menganalisa sebuah teks dalam konteks literernya. Dalam analisis retorik, makna teks tidak ditemukan dalam satu teks secara partikular, melainkan dalam interaksi antar teks yang menjadi bagian dalam kesatuan unitnya. Tugas seorang penafsir adalah untuk menganalisa kesinambungan atau perkembangan pesan antar makna-makna teks yang ada di dalam satu unit teks secara kolektif. ${ }^{40}$

Ketiga, tujuan utama analisis retorik adalah mengetahui dampak persuasif teks. Analisis retorik melihat teks final Alkitab sebagai sebuah karya persuasif di mana ide sang penulis sengaja dimasukkan ke dalam argumentasi-argumentasi yang disusun secara strategis untuk menghasilkan dampak paling efektif sehingga akhirnya pembacanya setuju dan mengikuti ide utama penulis. ${ }^{41}$ Untuk mengetahui dampak persuasif sebuah teks maka seorang penafsir harus menganalisa

and The Power of Historical Recitation," 341; Patrick dan Scult, Rhetoric and Biblical Interpretation, 14, 17.

40. Lundbom, Biblical Rhetoric and Rhetorical Criticism, 34; Lundbom, Jeremiah 1-20, 87.

41. Philip H. Kern, Rhetoric and Galatians: Assesing an Approach to Paul's Epistle, ed. Richard Bauckham, Society for New Testaments-Monograph Series (Cambridge: Cambridge, 2008), 8 mendefinisikan retorika sebagai sebuah strategi komunikasi di mana kata-kata digunakan secara efektif untuk meyakinkan pembacanya agar ikut menyetujui ide pokok sang retor. Menurut Jonathan Culler, Literary Theory: A Very Short Introduction (Oxford: Oxford, 1997), 70, retorika adalah sebuah teknik bahasa komunikasi yang bertujuan untuk membujuk para pembacanya kepada sebuah ide tertentu melalui sebuah diskursus yang efektif. Sementara itu, J. David Hester, "The Wuellnerian Sublime: Rhetorics, Power and the Ethics of Commun(icat)ion," dalam Rhetorics and Hermeneutics, ed. oleh James D. Hester dan J. David Hester (London: T \& T Clark, 2004), 11 menyatakan bahwa esensi dari retorika bukanlah sekadar komunikasi atau penyampaian informasi, melainkan menciptakan kesatuan ide antara pendengar atau pembaca dengan sang retor. 
komponen-komponen teks, seperti genre teks, gaya bahasa, repetisi kata, struktur teks, pemilihan kata-kata yang dipakai, dan kemudian menelaah fungsi dari setiap komponen ini dalam menimbulkan dampak yang diharapkan. ${ }^{42}$

Keempat, analisis retorik melihat makna dan tujuan penulisan teks dari sudut pandang respons pembaca. Dalam analisis retorik, hal yang terpenting bukanlah penulis atau teks melainkan pembacanya. Untuk pembacalah sebuah teks ditulis dan bagaimana pesan sebuah teks diterima adalah tergantung dari interpretasi pembacanya. ${ }^{43}$ Dengan kata lain, makna dan tujuan penulisan teks tidak terletak secara inheren di dalam diri penulis atau di dalam teks itu sendiri, melainkan di dalam interaksi yang terjadi antara teks dengan pembaca. ${ }^{44}$ Penekanan kepada pembaca inilah yang menjadikan analisis retorik sering disebut sebagai metode yang menekankan respons pembaca. ${ }^{45}$ Ini tidak berarti bahwa pembaca bisa menafsirkan sebuah teks secara sembarangan,

42. Lundbom, Jeremiah 1-20, 68 menyatakan kesamaan pendapatnya dengan Baumgartner bahwa konfesi Yeremia masuk ke dalam genre mazmur ratapan individual. Sekalipun, berbeda dengan Baumgartner, Lundbom tetap melihat konfesi Yeremia memiliki fungsi publik. Menurutnya, sangat mungkin awalnya konfesi Yeremia ditulis untuk tujuan personal, tetapi dalam bentuk finalnya, konfesi Yeremia jelas memiliki fungsi publik secara retoris. Lundbom, Jeremiah: A Study in Ancient Hebrew Rhetoric, xxxiii mengemukakan bahwa konfesi Yeremia, pada masa kemudian, sengaja digunakan untuk melayani kebutuhan umat beriman, sehingga sekalipun konfesi Yeremia memiliki gaya bahasa yang personal, tetapi tujuannya tetap adalah untuk kepentingan bersama.

43. Lundbom, Jeremiah: A Study in Ancient Hebrew Rhetoric, xxii.

44. Patrick dan Scult, Rhetoric and Biblical Interpretation, 19.

45. Boadt, "The Book of Jeremiah and The Power of Historical Recitation," 347. 
sebab di dalam teks penulis sudah meletakkan petunjuk-petunjuk yang mengatur bagaimana sebuah teks harus ditafsirkan. Ini juga tidak berarti bahwa maksud penulis menjadi tidak penting, melainkan ini berarti bahwa makna dan tujuan penulisan bisa dilihat dari dampak yang hendak dihasilkan teks kepada pembaca. ${ }^{46}$ Analisis retorik berargumentasi bahwa konfesi-konfesi Yeremia sengaja diredaksi sampai ke dalam bentuk dan susunan finalnya di konteks pasal 11-20 karena keyakinan para editor akan keefektifannya dalam menyampaikan makna yang koheren kepada pembaca asli. Bentuk dan susunan final konfesi-konfesi Yeremia dalam konteks pasal 11-20 mungkin membingungkan dan terlihat dipaksakan bagi pembaca masa kini, tapi tidak demikian bagi para pembaca pertama. Oleh sebab itu, titik awal yang tepat untuk menemukan makna utama dan tujuan penulisan adalah dengan melihat respons pembaca asli terhadap teks. ${ }^{47}$

Menurut penulis, dalam kasus konfesi-konfesi Yeremia, analisis retorik memang merupakan metode penafsiran yang paling tepat. Pertama, bentuk final konfesi Yeremia yang kompleks dan begitu terjalin satu sama lain memang tidak memungkinkan kita untuk menerima bentuk lain kecuali teks final. Hal ini jelas sesuai dengan karakteristik analisis retorik yang menyelidiki sebuah teks dalam bentuk finalnya. Kedua, penempatan konfesi-konfesi Yeremia secara nonkronologis

46. Menurut Patrick dan Scult, Rhetoric and Biblical Interpretation, 15, tidaklah berlebihan jika dikatakan bahwa topik utama analisis retorik adalah dampak teks kepada pembaca.

47. Untuk keterangan lebih jauh lihat Lundbom, Jeremiah: A Study in Ancient Hebrew Rhetoric, xxiii-xxiv, xxix-xxx, xxxiii, 9,152; Lundbom, Jeremiah 120, 68, 70-73, 84-85; Lundbom, Jeremiah Closer Up, 81. 
dalam konteks pasal 11-20 memang menunjukkan adanya kesengajaan penulis untuk menggabungkan kelima nas ini sebagai satu unit dalam rangka menyatakan pesan teologis yang koheren. Hal ini sesuai dengan karakteristik analisis retorik yang menyelidiki teks di dalam konteks literernya. Ketiga, penggambaran figur Yeremia dan deskripsi penderitaan sang nabi yang sangat personal dalam konfesi-konfesinya menunjukkan usaha penulis dalam menggugah pembacanya secara emosional dalam rangka membuat pembacanya setuju dengan ide utama penulis. ${ }^{48} \mathrm{Hal}$ ini sesuai dengan karakteristik analisis retorik yang melihat teks sebagai karya persuasif. Ketiga poin ini menunjukkan bahwa teks konfesi Yeremia memang memiliki kesesuaian dengan karakteristik analisis retorik.

\section{Kesimpulan}

Melihat kepada berbagai metode penafsiran yang digunakan dalam eksegesis konfesi-konfesi Yeremia, penulis menyimpulkan bahwa perkembangan penafsiran konfesi-konfesi Yeremia telah menuju ke arah yang tepat. Natur konfesi Yeremia sebagai sebuah teks yang diredaksi dengan tujuan teologis tertentu dan disampaikan kepada pembaca tertentu, tidak mengizinkan dirinya ditafsirkan dengan penafsiran biografis yang serta-merta hanya melihat makna teks bagi pembaca masa kini. Sementara itu, bentuk dan susunan teks konfesikonfesi Yeremia yang kompleks dan terjalin satu sama lain, tidak

48. Diamond, "The Confessions of Jeremiah in Context," 178; Bedard, "The 'Pain-Filled Necessity' of Judgment," 78. 
mengizinkan dirinya ditafsirkan dengan metode penafsiran historis-kritis yang selalu berusaha mengembalikan teks kepada bentuk dan susunannya yang paling awal. Oleh sebab itu, dibutuhkan metode yang dapat menafsirkan pesan teologis konfesi-konfesi Yeremia bagi pembaca asli di dalam bentuk finalnya. Kebutuhan inilah yang dijawab oleh analisis retorik.

\section{Daftar Pustaka}

Allen, Leslie C. "The Value of Rhetorical Criticsm in Psalm 69." JBL 105/4 (1986): 577-98.

Anderson, Jr., R. Dean. Ancient Rhetorical Theory and Paul. Edisi revisi. Leuven: Peeters, 1999.

Andrews, James. "Why Theological Hermeneutics Needs Rhetoric: Augustine's De doctrina Christiana." IJST 12/2 (2010): 184-200.

Avioz, Michael. "The Call For Revenge in Jeremiah's Complaints (Jer XIXX)." Vetus Testamentum 55/4 (2005): 429-38.

Bedard, Rebekah Jean. "The 'Pain-Filled Necessity' of Judgment:The Function of Jeremiah's Laments in Jeremiah 11-20." University of St. Michael's College, 2010.

Blank, Sheldon H. Jeremiah: Man and The Prophet. Cincinnati: Hebrew Union College, 1961.

. "The Confessions of Jeremiah and The Meaning of Prayer."

Hebrew Union College Annual 21 (1948): 331-54.

Boadt, Lawrence. "The Book of Jeremiah and The Power of Historical Recitation." Dalam Troubling Jeremiah. JSOT Supplement Series 260, 1999.

Bright, John. "A Prophet's Lament and It's Answer: Jeremiah 15:10-21."

Disunting oleh James L. Mays. Interpretation 28/1 (1974): 59-74. . Jeremiah. The Anchor Bible 21. Garden City: Doubleday, 1981. . Jeremiah: Introduction, Translation, and Notes. The Anchor

Bible. New York: Doubleday, 1965.

Brueggemann, Walter. A Commentary on Jeremiah-Exile and Homecoming. Grand Rapids: Eerdmans, 1998. 
. Like Fire in the Bones: Listening for the Prophetic Word in Jeremiah. Disunting oleh Patrick D. Miller. Minneapolis: Fortress, 2006.

. "Next Steps in Jeremiah Studies?" Dalam Trouble Jeremiah. JSOT Supplement Series 260, 1999.

. The Theology of The Book of Jeremiah. Cambridge: Cambridge University Press, 2007.

Busch, Roger Vanden. "Jeremiah: A Spiritual Metamorphosis." Biblical Theology Bulletin 10/1 (1980): 17-24.

Carroll, Robert P. From Chaos to Covenant: Uses of Prophecy in The Book of Jeremiah. London: SCM, 1981.

Cheyne, T. K. Jeremiah, Lamentations. Disunting oleh H. D. M. Spence dan Joseph S. Exell. The Pulpit Commentary vol. 11. Peabody: Hendrickson, 1985.

Childs, Brevard S. Biblical Theology of the Old and New Testaments: Theological Reflection on The Christian Bible. Minneapolis: Fortress, t.t.

. Introduction to the Old Testament as Scripture. Philadelphia: Fortress, 1979.

. Old Testament Theology in a Canonical Context. Philadelphia: Fortress, 1985.

. The Struggle to Understand Isaiah as Christian Scripture. Grand Rapids: Eerdmans, 2004.

Compier, Don H. What is Rhetorical Theology? Harrisburg: Trinity, 1999. Craigie, Peter C., Page H. Kelley, dan Joel F. Drinkard Jr. Jeremiah 1-25. Word Biblical Commentary 26. Nashville: Thomas Nelson, 1991.

Culler, Jonathan. Literary Theory: A Very Short Introduction. Oxford: Oxford, 1997.

Devolder, Rachelle. "The Sufferings of The Prophet of Jeremiah and Their Results." Tesis, University of Ottawa, 1971.

Diamond, A. R. "The Confessions of Jeremiah in Context-Scene of Prophetic Drama." JSOT Supplement Series 45, 1987.

Dimant, Devorah. "From The Book of Jeremiah to the Qumranic Apocryphon of Jeremiah." Dead Sea Discoveries 20 (2013): 45271.

Dinkler, Michal Beth. "New Testament Rhetorical Narratology: An Invitation toward Integration." JBL 24 (2016): 203-28. 
Driver, Daniel R. "Childs as Biblical Theologian." Dalam The Bible as

Christian Scripture: The Work of Brevard S. Childs. SBL Supplement

Series 25. Atlanta: SBL, 2013.

Duhm, Bernhard. Das Buch Jeremia. Charleston: Nabu Press, 2011.

Fretheim, Terence E. Jeremiah. Smyth \& Helwys Bible Commentary. Georgia: Smyth \& Helwys, 2002.

Goldingay, John. God's Prophet God's Servant: A Study in Jeremiah and Isaiah 40-55. Greenwood: Attic, 1984.

Greenwood, David. "Rhetorical Criticism and Formgeschichte: Some Methodological Considerations." JBL 89 (1970): 418-26.

Harmon, Nolan B., ed. "Jeremiah", dalam The Interpreter's Bible. Vol. VI. 12 vol. New York: Abingdon, 1956.

Harrisville, Roy A., dan Walter Sundberg. The Bible in Modern Culture:

Baruch Spinoza to Brevard Childs. 2nd Edition. Grand Rapids: Eerdmans, 2002.

Hester, J. David. "The Wuellnerian Sublime: Rhetorics, Power and the Ethics of Commun(icat)ion." Dalam Rhetorics and Hermeneutics, disunting oleh James D. Hester dan J. David Hester. London: T \& T Clark, 2004.

Holladay, William L. "Indications of Jeremiah's Psalter." Journal of Biblical Literature 121/2 (2002): 245-61.

Keil, C. F. "Jeremiah, Lamentations." dalam Commentary on the Old Testament in Ten Volumes, oleh C. F. Keil dan F. Delitzsch, Vol. VIII. Grand Rapids: Eerdmans, t.t.

Kern, Philip H. Rhetoric and Galatians: Assessing an Approach to Paul's Epistle. Disunting oleh Richard Bauckham. Society for New Testaments-Monograph Series. Cambridge: Cambridge, 2008.

King, Philip J. Jeremiah: An Archeological Companion. Louisville: Westminster, 1993.

Longman III, Tremper. Jeremiah, Lamentations. New International Biblical Commentary. Peabody: Hendrickson, 2008.

Lundbom, Jack R. Biblical Rhetoric and Rhetorical Criticism. Hebrew Bible Monographs 45. Sheffield: Sheffield Phoenix Press, 2015. . Jeremiah 1-20: A New Translation with Introduction and Commentary. The Anchor Yale Bible. London: Yale University Press, 2009. 
. Jeremiah: A Study in Ancient Hebrew Rhetoric. Winona Lake: Eisenbrauns, 1997.

. Jeremiah Among The Prophets. Eugene: Cascade Books, 2012. . "Jeremiah, Book of." Dalam The Anchor Bible Dictionary vol. 3:

$\mathrm{H}-\mathrm{J}$, disunting oleh David Noel Freedman. New York: Doubleday, 1992.

. Jeremiah Closer Up: The Prophet and The Book. University of Sheffield: Sheffield, 2010.

Miller, Jr., Patrick D. "Trouble and Woe: Interpreting The Biblical Laments." Interpretation 37 (1983): 32-45.

Mowinckel, Sigmund. Zur Komposition Des Buches Jeremia. USA: Wentworth, 2016.

Neil, William. Bible Guides 8: Prophets of Israel vol. 2: Jeremiah and Ezekiel. Disunting oleh William Barclay dan F. F. Bruce. New York: Abingdon, 1964.

Nicholson, Ernest W. The Book of The Prophet Jeremiah-Chapters 1-25. London: Cambridge University Press, 1973.

O'Connor, Kathleen M. Jeremiah: Pain and Promise. Minneapolis: Fortress, 2011.

. "The Confessions of Jeremiah: Their Interpretation and Role in Chapters 1-25." Society of Biblical Literature, Dissertation Series, 94 (1988).

. "The Prophet of Jeremiah and Exclusive Loyalty to God." Vocation 59/2 (2005): 130-40.

. "The Tears of God and Divine Encounter." Dalam Troubling Jeremiah. JSOT Supplement Series 260, England: Sheffiled Academics Press, 1999.

Parke-Taylor, Geoffrey H. The Formation of The Book of Jeremiah: Doublets and Recurring Phrases. Monograph Series 51. Atlanta: Society of Biblical Literature, 2000.

Patrick, Dale, dan Allen Scult. Rhetoric and Biblical Interpretation. Sheffield: The Almond Press, 1990.

Perdue, Leo G. "The Book of Jeremiah in old Testament Theology." Dalam Troubling Jeremiah. JSOT Supplement Series 260, England: Sheffiled Academics Press, 1999. 
Polk, Timothy. The Prophetic Persona: Jeremiah and The Language of Self. Disunting oleh David J. A. Clines dan Philip R. Davies. JSOT Supplement Series 32, 1984.

Rad, Gerhard von. Old Testament Theology. Vol. 2. New York: Harper \& Row, 1965.

. The Message of the Prophets. Diterjemahkan oleh D. M. G. Stalker. New York: Harper Collins, 1965.

Routledge, Robin. Old Testament Theology: A Thematic Approach. Nottingham, England: Apollos, 2008.

Rowe, C. Kavin. "The Doctrine of God Is a Hermeneutic: The Biblical Theology of Brevard S. Childs." Dalam The Bible as Christian Scripture-The Work of Brevard S. Childs. SBL Supplement Series 25. Atlanta: SBL, 2013.

Rowley, H. H. "The Prophet and Jeremiah and The Book of Deuteronomy." Dalam Studies in Old Testament Prophecy, disunting oleh H. H. Rowley. New York: T \& T Clark, 1957.

Seitz, Christopher R. "Tribute to Brevard S. Childs at The International SBL Meeting in Vienna, Austria." Dalam The Bible as Christian Scripture-The Work of Brevard S. Childs. SBL Supplement Series 25. Atlanta: SBL, 2013.

Siebert, Dorothy E. "Jeremiah: A Model for Response to Persecution and Threats of Violence." Tesis M.A., Providence Theological Seminary, 2007.

Siegfried, Herrmann. "Overcoming the Israelite Crisis. Remarks on the Interpretation of the Book of Jeremiah." Dalam A Prophet to the Nations: Essays in Jeremiah Studies, disunting oleh Leo G. Perdue dan Brian W. Kovacs, diterjemahkan oleh Leo G. Perdue. Winona Lake: Eisenbrauns, 1984.

Skinner, John. Prophecy and Religion: Studies in The Life Of Jeremiah. Cambridge: The Syndics of The Cambridge University Press, 1963. Smith, Mark S. The Laments of Jeremiah and Their Contexts - A Literary and Redactional Study of Jeremiah 11-20. Atlanta, Georgia: Scholars Press, 1990.

Thiele, David. The Identity of the "I" of the Confessions of Jeremiah. Lambert, 2014.

Thompson, J. A. The Book of Jeremiah. Grand Rapids: Eerdmans, 1980. 
VanGemeren, Willem A. Interpreting The Prophetic Word: an Introduction to the Prophetic Literature of the Old Testament. Grand Rapids: Zondervan, 2002.

Wuellner, Wilhelm. "Reconceiving a Rhetoric of Religion: A Rhetoric of Power as the Power of The Sublime." Dalam Rhetorics and Hermeneutics. Disunting oleh James D. Hester dan J. David Hester. London: T \& T Clark, 2004. 